\title{
PENGARUH LATIHAN YOGA TERHADAP KADAR GLUKOSA DARAH PUASA PADA WANITA DEWASA AWAL
}

\author{
Chantika Lady, Fillah Fithra Dieny", Enny Probosari \\ Departemen Ilmu Gizi, Fakultas Kedokteran, Universitas Diponegoro \\ Jl. Prof. Sudarto SH, Tembalang, Semarang, Jawa Tengah 50275, Indonesia \\ "Penulis Penanggungjawab. E-mail: fillahdieny@gmail.com
}

\begin{abstract}
Background: More than $90 \%$ patients of diabetes are also suffered from obese. The American Diabetes Association recommends a moderate-intensity exercise, like yoga, in order to control blood glucose and lipid profiles. This study aims to determine the effect of yoga practices on Fasting Blood Glucose (FBG) in women in early adulthood.

Methods: A quasi-experiment study was conducted by using pre-post test with control group design. The subjects were 22 women aged 19-25 that later divided into two groups; treatment group who received 60 minutes of yoga practice 10 times in 20 days and nutritional education, and control group who only received nutritional education. Fasting Blood Glucose data were measured using spectrophotometry method in Glucocard TM Test Strip tools, while food intake data were acquired with Food Recall questionnaires. Data were analyzed by Wilcoxon and Mann-Whitney Test and regresi linier.

Result: In treatment group, there was a significant decrease $(p=0.01)$ of Fasing Blood Glucose from $113.64 \mathrm{mg} / \mathrm{dl} \pm$ 55.24 to $102 \mathrm{mg} / \mathrm{dl} \pm 52.69$, while in control group, the decrease from $117.73 \mathrm{mg} / \mathrm{dl} \pm 60.32$ to $110.73 \mathrm{mg} / \mathrm{dl} \pm 65.47$ was unsignificant $(p=0.18)$. Both groups' Fasting Blood Glucose difference were unsignificant $(p=0.18)$. The treatment group's delta Fasting Blood Glucose difference was $11.63 \mathrm{mg} / \mathrm{dl} \pm 11.77$, while in the control group was $7.00 \mathrm{mg} / \mathrm{dl} \pm$ 17.07. Yoga practice resulted no significant reduction on the Fasting Blood Glucose in early adulthood women who were overweight $(p>0.05)$

Conclusion: Yoga practice 10 times in early adulthood women with obese had no significant effect on decreasing Fasting Blood Glucose level.
\end{abstract}

Kata kunci : yoga; fasting blood glucose; obese; women

\begin{abstract}
ABSTRAK
Latar Belakang : Lebih dari 90\% penderita diabetes mellitus berstatus gizi obesitas. Olahraga yang tepat dilakukan dan direkomendasikan oleh American Diabetes Association dalam mengontrol kadar glukosa darah dan profil lipid adalah olahraga dengan intensitas sedang, seperti yoga. Penelitian ini bertujuan untuk mengetahui pengaruh latihan yoga terhadap kadar glukosa darah puasa (GDP) pada wanita dengan kelebihan berat badan.

Metode: Penelitian quasi experiment dengan rancangan pre-post test with control group design sebanyak 22 subjek dan dipilih dengan menggunakan metode consecutive sampling, dibagi menjadi 2 kelompok dengan metode simple randomization. Subjek penelitian adalah 22 wanita usia 19-25 tahun yang dibagi menjadi 2 kelompok, yaitu kelompok perlakuan mendapat latihan yoga 60 menit sebanyak 10 kali selama 20 hari dan edukasi gizi, dan kelompok kontrol hanya mendapatkan edukasi gizi. Data glukosa darah puasa diukur 2 kali yaitu sebelum dan sesudah penelitian dengan alat spektofotometri dengan metode Glucocard TM Test Strip; sedangkan data asupan makanan diambil sebanyak 5 kali selama intervensi berlangsung dengan menggunakan metode Food Recall. Data dianalisis dengan uji Wilcoxon, Uji Mann Whitney, dan regresi linier untuk variable perancu selama intervensi.

Hasil : Terdapat penurunan nilai Glukosa Darah Puasa yang bermakna $(p=0,01)$ pada kelompok perlakuan dengan nilai GDP dari 113,64 mg/dl \pm 55,24 menjadi $102 \mathrm{mg} / \mathrm{dl} \pm$ 52,69. Pada kelompok kontrol ada penurunan GDP namun tidak bermakna $(p=0,18)$ yaitu 117,73 mg/dl $\pm 60,32$ menjadi 110,73 mg/dl $\pm 65,47$. Berdasarkan selisih penurunan GDP antara kelompok perlakuan lebih besar $(11,63 \mathrm{mg} / \mathrm{dl} \pm 11,77)$ dibanding kelompok kontrol (7,00 $\mathrm{mg} / \mathrm{dl} \pm$ 17,07).Namun selisih GDP pada kedua kelompok setelah intervensi latihan yoga tidak bermakna $(p=0,18)$.
\end{abstract}

Kesimpulan : Latihan yoga selama 10 kali pada wanita obesitas tidak signifikan berpengaruh terhadap penurunan kadar glukosa darah puasa.

Kata kunci : yoga; glukosa darah; obesitas; wanita

\section{PENDAHULUAN}

Diabetes mellitus (DM) merupakan suatu kelompok penyakit metabolik dengan karakteristik hiperglikemia yang terjadi karena kelainan sekresi insulin, kerja insulin atau kedua-duanya. Menurut Perkumpulan Endokrinologi Indonesia (PERKENI) diagnosis Diabetes Melitus selalu ditegakkan atas dasar pemeriksaan kadar glukosa darah, baik itu 
glukosa darah puasa atau glukosa darah postprandial. ${ }^{1}$

Persentase penderita diabetes mellitus di dunia diperkirakan $4 \%$ dari total populasi dan angka tersebut akan terus meningkat menjadi 5,4\% di tahun 2025. Tahun 2030 penderita diabetes mellitus di negara maju diperkirakan akan mencapai 48 juta sedangkan di negara berkembang mencapai 82 juta orang. ${ }^{2}$ Berdasarkan Riskesdas 2013 persentase diabetes mellitus meningkat $1 \%$ dari tahun 2007 menjadi $2,1 \%$ ditahun 2013. Sedangkan prevalensi diabetes mellitus di Jawa Tengah sebesar 1,6\%. Menurut data RISKESDAS 2007, prevalensi nasional DM di Indonesia untuk usia di atas 15 tahun sebesar $5,7 \%{ }^{1}$

Lebih dari $90 \%$ penderita diabetes mellitus adalah penderita kegemukan. Obesitas adalah kelebihan lemak dalam tubuh, yang umumnya ditimbun dalam jaringan subkutan, sekitar organ tubuh dan kadang terjadi perluasan ke dalam jaringan organnya. ${ }^{3}$ Berdasarkan Riskesdas 2013, prevalensi penduduk obesitas perempuan dengan usai $>18$ tahun lebih tinggi dibandingkan laki-laki pada tahun 2013 sebanyak 32,9\% dan 19,7\%. Prevalensi obesitas perempuan dewasa semakin meningkat yaitu pada tahun 2013 sebanyak $32,9 \%$, naik $18,1 \%$ dari tahun $2007(13,9 \%)$ dan naik 17,5\% dari tahun 2010 $(15,5 \%){ }^{4}$

Selain mengatur asupan makan, dan lifestyle, aktivitas fisik terutama olahraga juga berpengaruh terhadap kegemukan. Olahraga yang tepat dilakukan dan direkomendasikan oleh American Diabetes Association dalam mengontrol kadar glukosa darah dan profil lipid adalah olahraga dengan intensitas sedang, seperti yoga. ${ }^{5,6}$

Yoga merupakan intervensi holistik yang menggabungkan postur tubuh (asanas), teknik pernapasan (pranayamas), teknik meditasi (dhyana), dan irama (mantras) untuk menyatukan antara tubuh dan pikiran. $^{7}$ Penelitian menunjukkan bahwa yoga merupakan salah satu bentuk latihan fisik yang efektif mengontrol kadar gula darah, sehingga menjadi alternatif terapeutik sederhana dan ekonomis untuk pasien obesitas. ${ }^{7}$ Berdasarkan beberapa penelitian yang telah dilakukan, yoga merupakan olahraga aman dan efektif yang mempunyai beberapa manfaat bagi kesehatan, diantaranya dalam pengontrolan berat badan dan pengontrolan glukosa darah pada penderita diabetes mellitus tipe $2.8,9$

Pada penelitian sebelumnya menunjukkan bahwa adanya penurunan kadar glukosa darah sewaktu dan kadar glukosa darah puasa pada kelompok yang diberi perlakuan latihan yoga dengan durasi 45 menit dalam tiga kali seminggu dalam selama 12 minggu. ${ }^{10}$ Penelitian lain menunjukkan bahwa hatha yoga secara signifikan menurunkan kadar glukosa darah puasa setelah 6 bulan latihan. ${ }^{11}$ Penelitian yang dilakukan oleh Malhotra et al juga menunjukkan adanya penurunan kadar glukosa darah puasa setelah intervensi selama 40 hari dengan asanas yoga. ${ }^{12}$ Penelitian yang dilakukan oleh Sahay et al. menunjukkan adanya penurunan yang yang signifikan pada kadar glukosa darah sewaktu dan glukosa darah puasa dalam 3 bulan pemberian intervensi yoga pada pasien diabetes mellitus tipe $2 .{ }^{13}$ Penelitian yang sama juga dilakukan oleh Mercuri et al. dan menunjukkan adanya penurunan glikemia setelah 3 bulan pemberian latihan yoga. ${ }^{14}$ Berdasarkan masalah tersebut, maka peneliti tertarik untuk melihat adanya pengaruh latihan yoga terhadap kadar glukosa darah puasa pada wanita dewasa awal dengan kelebihan berat badan.

\section{METODE}

Penelitian ini dilakukan di Studio Senam Dee's Tembalang pada bulan Mei 2017. Desain yang digunakan dalam penelitian ini adalah quasi experimental dengan rancangan pre-post test with control design. Populasi dalam penelitian ini adalah seluruh wanita dewasa muda usia 19-25 tahun yang memenuhi kriteria inklusi di Kota Semarang.

Pemilihan subjek menggunakan metode consecutive sampling sebanyak 24 orang dan dibagi menjadi 2 kelompok dengan metode simple randomization, yaitu kelompok perlakuan dan kontrol. Namun, hanya 22 orang yang mengikuti hingga penelitian selesai yaitu 11 orang perlakuan dan 11 orang kontrol. Kriteria inklusi pada penelitian ini diantaranya adalah wanita dewasa awal berusia 19-25 tahun, overweight atau obesitas (IMT $\geq 23$ $\mathrm{kg} / \mathrm{m}^{2}$ ), kadar Glukosa Darah Puasa $\geq 90$, tidak mengkonsumsi obat diabetes mellitus, tidak mengikuti aktivitas fisik khusus, dan bersedia menjadi subjek penelitian dengan menandatangani informed consent. Sedangkan kriteria eksklusi penelitian ini adalah tidak rutin hadir pada saat intervensi yoga dan mengundurkan diri saat penelitian berlangsung.

Variabel bebas dalam penelitian ini adalah latihan yoga sedangkan variabel terikat adalah Glukosa Darah Puasa (GDP). Latihan yoga merupakan intervensi holistic yang menggabungkan postur tubuh (asanas), teknik pernapasan (pranayamas) dan meditasi. Latihan ini diberikan dengan durasi 60 menit sebanyak 10 kali dan dilakukan dua hari sekali selama 20 hari pada kelompok perlakuan. Hasil pengukuran glukosa darah puasa subjek penelitian diambil melalui pembuluh darah kapiler sebanyak 2 kali oleh enumerator terlatih (pre dan post intervensi) setelah sebelumnya subjek penelitian telah melakukan puasa 8 jam. Pengukuran kadar glukosa darah 
menggunakan alat spektofotometri dengan metode Glucocard TM Test Strip. Variabel perancu dalam penelitian ini adalah asupan makanan yang meliputi asupan energi, karbohidrat, protein, lemak, dan serat. Pengambilan data asupan makanan selama intervensi mengunakan food recall 24 jam sebanyak 5 kali dengan pengambilan data berseling atau tidak berurutan. Data asupan diambil selama intervensi yoga berlangsung. Data yang diperoleh akan dihitung dalam bentuk URT, dikonversikan dalam satuan kalori dan dihitung dengan menggunakan nutrisurvey.

Pemilihan subjek penelitian dilakukan melalui skrining menurut kriteria inklusi. Skrining awal berupa pengukuran antropometri yang meliputi berat badan dan tinggi badan, pengukuran biokimia yaitu GDP dan wawancara data umum subjek. Sehari sebelumnya subjek yang akan diskrining telah diminta untuk melakukan puasa tidak mengonsumsi makanan dan minuman apapun selain air putih selama 8 jam. Subjek yang memenuhi kriteria inklusi dimohon kesediaannya untuk menjadi subjek penelitian dengan mengisi informed consent. Setelah itu, subjek dibagi secara acak menjadi 2 kelompok, yaitu kelompok perlakuan dan kelompok kontrol. Kedua kelompok diberikan edukasi gizi mengenai aktivitas fisik dan pola makan sebelum dilakukan intervensi. Kemudian kelompok perlakuan diberikan intervensi berupa latihan yoga sebanyak 10 kali dan dipantau asupannya melalui food recall 24 jam, sedangkan pada kelompok kontrol hanya dilakukan pemantauan asupan makan melalui metode yang sama. Setelah intevensi yaitu pada hari ke-20 akan dilakukan pengukuran GDP pada kedua kelompok, dengan sebelumnya masing-masing subjek diminta untuk melakukan puasa selama 8 jam.

Uji statistik yang digunakan untuk melihat perbedaan data biokimia sebelum dan sesudah intervensi tiap kelompok adalah Uji Wilcoxon. Sedangkan untuk melihat perbedaan data asupan makanan antara kelompok perlakuan dan kontrol selama intervensi dianalisis dengan menggunakan Uji Independent t-test dan Uji Mann Whitney.

\section{HASIL \\ Karakteristik Subjek}

Karakteristik subjek yang terdiri dari berat badan, tinggi badan, indeks masa tubuh (IMT), glukosa darah puasa (GDP) pre dan post intervensi pada kelompok perlakuan dan kelompok kontrol pre intervensi disajikan dalam Tabel 1.

Tabel 1. Karakteristik Subjek Penelitian Sebelum Intervensi $(n=22)$

\begin{tabular}{|c|c|c|c|c|c|c|c|}
\hline \multirow{2}{*}{ Karakteristik Subjek } & \multicolumn{3}{|c|}{ Perlakuan $(n=11)$} & \multicolumn{3}{|c|}{ Kontrol $(n=11)$} & \multirow[t]{2}{*}{$\mathbf{p}$} \\
\hline & Min & Maks & Rerata \pm SD & Min & Maks & Rerata \pm SD & \\
\hline Berat Badan (kg) & 55,2 & 74,7 & $65,48 \pm 6,33$ & 55,6 & 95,1 & $73,8 \pm 11,59$ & $0,04^{\mathrm{a}}$ \\
\hline Tinggi Badan $(\mathrm{cm})$ & 144,7 & 166,0 & $156,5 \pm 5,49$ & 148,5 & 162,0 & $156,7 \pm 4,38$ & $0,90^{\mathrm{a}}$ \\
\hline Indeks Massa Tubuh $\left(\mathrm{kg} / \mathrm{m}^{2}\right)$ & 23,5 & 29,9 & $26,8 \pm 2,24$ & 23,7 & 37,0 & $29,2 \pm 4,17$ & $0,10^{\mathrm{a}}$ \\
\hline GDP pre intervensi (mg/dl) & 90 & 279 & $113,64 \pm 55,24$ & 90 & 294 & $117,73 \pm 60,32$ & $0,94^{\mathrm{b}}$ \\
\hline GDP post intervensi (mg/dl) & 71 & 258 & $102 \pm 52,69$ & 77 & 306 & $110,73 \pm 65,47$ & $0,39^{\mathrm{b}}$ \\
\hline
\end{tabular}

Tabel 1 menunjukkan rerata berat badan pada kelompok perlakuan yaitu $65.48 \mathrm{~kg} \pm 6.33$, sedangkan pada kelompok kontrol yaitu $73.8 \mathrm{~kg} \pm$ 11.59. Pada kelompok perlakuan nilai rerata GDP pre intervensi sebesar $113.64 \mathrm{mg} / \mathrm{dl} \pm 55.24$, sedangkan pada nilai rerata GDP post intervensi sebesar 102 $\mathrm{mg} / \mathrm{dl} \pm 52.69$. Pada kelompok kontrol nilai rerata GDP pre intervensi sebesar $117.73 \mathrm{mg} / \mathrm{dl} \pm 60.32$, sedangkan nilai rerata GDP post intervensi sebesar $110.73 \mathrm{mg} / \mathrm{dl} \pm 65.47$.
Nilai berat badan menunjukkan terdapat perbedaan yang signifikan $(\mathrm{p}=0,04)$ antara 2 kelompok. Sedangkan nilai tinggi badan, indeks masa tubuh, serta glukosa darah puasa pre dan post intervensi menunjukkan tidak terdapat perbedaan yang signifikan antara 2 kelompok.

\section{Gambaran Glukosa Darah Puasa Subjek}

Gambaran subjek secara kategorik yang terdiri dari glukosa darah puasa (GDP) sebelum dan sesudah intervesi pada kelompok perlakuan dan kelompok kontrol disajikan dalam tabel 2.

Tabel 2. Gambaran Glukosa Darah Puasa Subjek Sebelum dan Sesudah Intervensi

\begin{tabular}{|c|c|c|c|c|c|c|c|c|}
\hline \multirow[t]{3}{*}{ Variabel } & \multicolumn{4}{|c|}{ Perlakuan } & \multicolumn{4}{|c|}{ Kontrol } \\
\hline & \multicolumn{2}{|c|}{ Pre } & \multicolumn{2}{|c|}{ Post } & \multicolumn{2}{|c|}{ Pre } & \multicolumn{2}{|c|}{ Post } \\
\hline & $\mathbf{n}$ & $\%$ & $\mathbf{n}$ & $\%$ & $\mathrm{n}$ & $\%$ & n & $\%$ \\
\hline \multicolumn{9}{|l|}{ GDP } \\
\hline$<90$ & 0 & 0 & 5 & 45,5 & 0 & 0 & 5 & 45,5 \\
\hline $90-100$ & 8 & 72,7 & 4 & 36,4 & 6 & 54,5 & 3 & 27,3 \\
\hline$>100$ & 3 & 27,3 & 2 & 18,2 & 5 & 45,5 & 3 & 27,3 \\
\hline Total & 11 & 100 & 11 & 100 & 11 & 100 & 11 & 100 \\
\hline
\end{tabular}


Tabel 2 menunjukkan bahwa seluruh glukosa darah puasa subjek pada kelompok perlakuan maupun kelompok kontrol berada diatas atau sama dengan 90. Hal tersebut menunjukkan bahwa seluruh subjek memenuhi kriteria untuk mengikuti penelitian ini, yaitu dengan memiliki nilai GDP diatas atau sama dengan 90.

Setelah dilakukan intervensi, terdapat penurunan nilai GDP pada kelompok perlakuan sebanyak 9 orang, namun terdapat peningkatan nilai GDP sebanyak 2 orang. Adapun penurunan tersebut dialami oleh subjek yang memiliki nilai GDP preintervensi antara 90-100 sebanyak 6 orang, dan nilai GDP pre-intervensi > 100 sebanyak 3 orang

Sedangkan itu penurunan nilai GDP pada kelompok kontrol sebanyak 8 orang dan peningkatan nilai GDP sebanyak 3 orang. Penurunan nilai GDP ini dialami oleh subjek yang memiliki nilai GDP preintervensi antara 90-100 sebanyak 5 orang, dan nilai GDP pre-intervensi $>100$ sebanyak 3 orang.
Perbedaan Glukosa Darah Puasa Sebelum dan Sesudah Intervensi pada Tiap Kelompok

Berdasarkan Tabel 3, diketahui bahwa pada kelompok perlakuan mengalami perbedaan bermakna $(\mathrm{p}=0,01)$ glukosa darah puasa sebelum dan sesudah intervensi dengan penurunan dari $113,64 \mathrm{mg} / \mathrm{dl} \pm$ 55,24 menjadi $102 \mathrm{mg} / \mathrm{dl} \pm 52,69$ sehingga rerata penurunan sebesar $11,64 \mathrm{mg} / \mathrm{dl} \pm 2,55$. Sedangkan pada kelompok kontrol tidak ada beda $(\mathrm{p}=0,18)$.

Selisih Glukosa Darah Puasa pada Kedua Kelompok

Selisih GDP disajikan untuk melihat selisih nilai GDP sebelum dan sesudah intervensi pada kedua kelompok. Berdasarkan Tabel 4, diketahui bahwa tidak ada perbedaan yang bermakna $(p=0,18)$ antara selisih nilai glukosa darah puasa sebelum dan sesudah intervensi pada kelompok perlakuan $(11.63 \mathrm{mg} / \mathrm{dl} \pm$ 11.77) dan kelompok kontrol (7.00 mg/dl \pm 17.07$)$.

Tabel 3. Perbedaan Glukosa Darah Puasa Sebelum dan Sesudah Intervensi pada Tiap Kelompok

\begin{tabular}{lccc}
\hline \multicolumn{1}{c}{ Variabel } & GDP Pre (mg/d) & GDP Post $(\mathbf{m g} / \mathbf{d l})$ & p \\
\hline Kelompok Perlakuan & $113,64 \pm 55,24$ & $102 \pm 52,69$ & $0,01^{\mathrm{c}}$ \\
GDP & $117,73 \pm 60,32$ & $110,73 \pm 65,47$ & $0,18^{\mathrm{c}}$ \\
Kelompok Kontrol &
\end{tabular}

${ }^{\mathrm{c}}$ Uji Wilcoxon

Tabel 4. Selisih Nilai GDP Sebelum dan Sesudah Intervensi pada Kedua Kelompok

\begin{tabular}{lccc}
\hline \multicolumn{1}{c}{ Variabel } & Perlakuan & Kontrol & p \\
\hline$\Delta$ GDP pre dan post intervensi $(\mathrm{mg} / \mathrm{dl})$ & $11,63 \pm 11,77$ & $7,00 \pm 17,07$ & $0,18^{\mathrm{b}}$ \\
\hline${ }^{\mathrm{b}}$ Uji Mann Whitney & & &
\end{tabular}

Tabel 5. Perbedaan Asupan Energi, Karbohidrat, Protein dan Lemak antara Kelompok Perlakuan dan Kontrol Selama Intervensi

\begin{tabular}{lrrr}
\hline Variabel & Perlakuan & Kontrol & p \\
\hline Asupan Energi (kkal) & $1699,05 \pm 201,65$ & $1842,86 \pm 413,36$ & $0,31^{\mathrm{a}}$ \\
Asupan Karbohidrat (gram) & $194,21 \pm 54,81$ & $181,8 \pm 58,15$ & $0,61^{\mathrm{a}}$ \\
Asupan Protein (gram) & $53,54 \pm 9,53$ & $68,57 \pm 10,14$ & $0,02^{\mathrm{a}}$ \\
Asupan Lemak (gram) & $79,13 \pm 11,7$ & $94,09 \pm 23,58$ & $0,74^{\mathrm{a}}$ \\
Asupan Serat (gram) & $7,28 \pm 2,05$ & $8,98 \pm 3,68$ & $0,17^{\mathrm{b}}$ \\
\hline
\end{tabular}

${ }^{\mathrm{a}} \mathrm{Uji}$ Independent $t$-test $;{ }^{\mathrm{b}} \mathrm{Uji}$ Mann Whitney

\section{Perbedaan Asupan Zat Gizi Selama Penelitian}

Nilai rerata asupan energi pada kelompok kontrol lebih besar dibandingkan pada kelompok perlakuan yaitu sebesar $143,81 \mathrm{kkal} \pm 211,71$. Sama halnya dengan energi, rerata asupan protein, lemak, dan serat pada kelompok kontrol selama intervensi didapatkan lebih besar dibanding dengan kelompok perlakuan. Sedangkan untuk rerata asupan karbohidrat pada kelompok perlakuan didapatkan lebih besar dibanding pada kelompok kontrol. Dari data tersebut diatas dinyatakan bahwa tidak terdapat perbedaan yang signifikan pada asupan energi, karbohidrat, lemak, dan serat antara kelompok perlakuan dan kelompok kontrol selama intervensi. Namun terdapat perbedaan yang signifikan $(p=0,02)$ asupan protein antara kelompok perlakuan dan kelompok kontrol. Perbedaan nilai tersebut disebabkan karena rerata perbedaan asupan protein pada kedua kelompok yang disebabkan oleh perbedaan jenis, jumlah, dan frekuensi asupan protein. 
Tabel 6. Pengaruh Asupan Zat Gizi terhadap Perubahan kadar Glukosa Darah Puasa

\begin{tabular}{ll}
\hline Variabel & p \\
\hline Asupan Energi (kkal) & $0.990^{\mathrm{d}}$ \\
Asupan Karbohidrat (gram) & $0.392^{\mathrm{d}}$ \\
Asupan Protein (gram) & $0.186^{\mathrm{d}}$ \\
Asupan Lemak (gram) & $0.563^{\mathrm{d}}$ \\
Asupan Serat (gram) & $0.592^{\mathrm{d}}$ \\
\hline
\end{tabular}

${ }^{\mathrm{d}}$ Uji Regresi Linier

\section{Pengaruh Asupan Zat Gizi terhadap Perubahan Kadar GDP}

Berdasarkan uji yang telah dilakukan, didapatkan bahwa tidak ada pengaruh kadar asupan zat gizi energi $(p=0,990)$, karbohidrat $(p=0,392)$, protein $(\mathrm{p}=0,186)$, lemak $(\mathrm{p}=0,563)$, dan serat $(\mathrm{p}=$ 0,592 ) terhadap perubahan kadar glukosa darah puasa pada subjek.

\section{PEMBAHASAN}

Pengumpulan data awal pada 24 orang dilakukan untuk mendapatkan subjek penelitian yang homogen dan sesuai dengan kriteria inklusi. Data tinggi badan, Indeks Massa Tubuh, Glukosa Darah Puasa sebelum dan sesudah intervensi, serta asupan makanan yaitu asupan energi, karbohidrat, lemak, dan serat tidak terdapat perbedaan yang signifikan pada 2 kelompok. Hal tersebut menunjukkan bahwa kedua kelompok dalam keadaan yang sama pada saat penelitian dilakukan. Rerata Glukosa Darah Puasa sebelum intervensi lebih besar pada kelompok kontrol dibandingkan kelompok perlakuan, demikian juga halnya dengan Glukosa Darah Puasa sesudah intervensi. Sedangkan secara kategorik, sebagian besar subjek penelitian memiliki nilai Glukosa Darah Puasa dalam rentang 90-100 mg/dl.

Yoga merupakan salah satu olahraga aerob dengan intensitas sedang yang mempertimbangkan aspek fisik untuk meningkatkan kebugaran serta direkomendasikan oleh American Diabetes Association dalam mengontrol kadar glukosa darah. ${ }^{5,6}$ Latihan yoga yang intensif dapat berkontribusi meningkatkan Basal Metabolic Rate (BMR) dan pembakaran energi hingga 250 kkal sehingga menyebabkan penurunan berat badan. Peningkatan kesadaran dan aktivitas fisik bisa dianggap sebagai mekanisme utama pada yoga yang dapat mempengaruhi bentuk tubuh dan berat badan. ${ }^{15,16}$ Seseorang dengan diabetes mellitus disarankan untuk melakukan latihan aerob selama 150 menit/minggu dan ditambah dengan 2 kali latihan ketahanan dalam satu minggu. ${ }^{5,6}$

Pada penelitian ini didapatkan bahwa ada penurunan nilai Glukosa Darah Puasa yang bermakna $(\mathrm{p}=0,01)$ pada kelompok perlakuan dengan rerata penurunan sebesar $11,64 \mathrm{mg} / \mathrm{dl} \pm 2,55$. Hal tersebut sesuai dengan penelitian yang telah diakukan sebelumnya, yaitu bahwa adanya penurunan kadar Glukosa Darah Sewaktu dan kadar Glukosa Darah Puasa pada kelompok yang diberi perlakuan latihan yoga dengan durasi 45 menit dalam tiga kali seminggu selama 12 minggu. ${ }^{10}$

Yoga memilliki hubungan dengan penurunan kadar glukosa darah. Meskipun menurut beberapa sumber menyatakan bahwa mekanisme latihan yoga terhadap penurunan kadar glukosa darah masih belum diketahui secara pasti, namun ada beberapa kemungkinan mekanisme penurunan yoga terhadap kadar glukosa darah, seperti variasi gerakan yoga secara langsung meremajakan sel pankreas sebagai hasil dari meningkatnya utilisasi dan metabolisme glukosa di jaringan perifer, liver, dan jaringan adipose sebagai proses enzimatik. ${ }^{17}$ Selain itu kemungkinan penurunan kadar glukosa darah oleh latihan yoga adalah terjadinya relaksasi muscular, peningkatan suplai darah ke otot yang dapat menambah ekspresi reseptor insulin pada otot, dan menyebabkan peningkatan pengambilan glukosa oleh otot sehingga mengurangi kadar glukosa dalam darah. ${ }^{12}$ Latihan yoga menyebabkan otot-otot untuk menyerap kelebihan glukosa dalam darah sehingga mencegah terjadinya resistensi insulin. ${ }^{18}$

Sedangkan pada kelompok kontrol ada penurunan namun tidak bermakna $(\mathrm{p}=0,18)$ pada nilai Glukosa Darah Puasa yaitu sebesar $117,73 \mathrm{mg} / \mathrm{dl}$ $\pm 60,32$ sebelum intervensi dan $110,73 \mathrm{mg} / \mathrm{dl} \pm 65,47$ sesudah intervensi. Adanya penurunan rerata kadar glukosa darah pada kelompok kontrol meskipun tidak diberikan intervensi, disebabkan oleh beberapa faktor penurun kadar glukosa, seperti keseimbangan hormone dan asupan makanan. Kedua faktor tersebut merupakan faktor yang tidak dikontrol dalam penelitian ini dan dapat menjadi penyebab penurunan kadar glukosa darah. Salah satu zat yang sangat berpengaruh terhadap kadar glukosa darah adalah karbohidrat. Dan berdasarkan hasil food recall pada subjek kelompok kontrol, didapatkan sumber makanan karbohidrat yang cukup tinggi pada asupan sehari-hari, walaupun kadarnya masih berada dibatas normal. Pemilihan jenis karbohidrat kompleks dengan indeks glikemik rendah dapat mengendalikan kadar glukosa darah. Selain itu rendahnya asupan lemak dan tingginya asupan serat juga menjadi salah satu faktor menurunnya kadar glukosa darah.

Pada penelitian ini jika dilihat dari selisih kadar glukosa darah puasa pada kedua kelompok tidak ada perbedaan yang bermakna $(\mathrm{p}=0,18)$. Kedua kelompok mengalami penurunan kadar GDP meskipun selisih penurunan sebelum dan sesudah intervensi lebih besar pada kelompok yang diberikan perlakuan. Selisih nilai GDP pada kelompok perlakuan sebesar $11,63 \mathrm{mg} / \mathrm{dl} \pm 11,77$, sedangkan 
pada kelompok kontrol sebesar 7,00 $\pm 17,07$. Dari data tersebut didapatkan selisih rerata kedua kelompok tidak terlalu jauh. Hal tersebut menyatakan bahwa selisih nilai Gukosa Darah Puasa pada kelompok yang diberikan latihan yoga dengan kelompok yang tidak diberikan latihan yoga tidak menunjukkan perbedaan yang signifikan. Hal tersebut tidak sesuai dengan beberapa penelitian yang telah dilakukan sebelumnya yang mengatakan bahwa latihan yoga berpengaruh pada nilai glukosa darah yang dilakukan dalam periode waktu tertentu, seperti 6 bulan, 3 bulan, atau 40 hari. $^{10,11,12,13,14}$ Ketidaksesuaian hasil penelitian ini dengan penelitian sebelumnya dapat dikarenakan beberapa faktor, seperti jumlah sampel yang kurang besar, waktu penelitian yang kurang lama, ketepatan gerakan yoga yang dilakukan oleh masing-masing subjek, maupun kepatuhan subjek dalam penelitian perihal pengontrolan asupan makan.

Dalam penelitian ini didapatkan rerata asupan energi, protein, lemak dan serat lebih rendah pada kelompok perlakuan dengan rerata masingmasing sebesar $1699.05 \mathrm{kkal} \pm 201,65,53,54 \mathrm{gr} \pm$ $9,53,79.13$ gr $\pm 11.7,7.28$ gr \pm 2.05 . Sedangkan untuk rerata asupan karbohidrat didapatkan lebih rendah pada kelompok kontrol dengan rerata sebesar 181.8 gr \pm 58.15. Penelitian ini menunjukkan ada perbedaan asupan energi, karbohidrat, lemak, dan serat selama intervensi pada kedua kelompok namun tidak bermakna. Asupan protein selama intervensi mengalami perbedaan yang bermakna $(p=0,02)$ pada kedua kelompok. Terdapat teori yang menyatakan bahwa yoga berpotensi merangsang perubahan perilaku makan. ${ }^{19}$ Meta analisis mengenai latihan yoga selama 12 minggu untuk orang kelebihan makan dengan jumlah subjek 25 wanita menunjukkan bahwa subjek merasakan mengalami pengurangan jumlah makanan yang mereka konsumsi, penurunan kecepatan makan, dan peningkatan kualitas dalam pilihan makanan selama program berlangsung. ${ }^{20} \mathrm{Hal}$ ini terbukti dari lebih rendahnya rerata asupan makan pada kelompok perlakuan yang diberikan latihan yoga dibanding kelompok kontrol.

Terdapat beberapa faktor yang mempengaruhi kadar glukosa darah. Selain faktor endogen yang sulit dikontrol, ada faktor eksogen yang dapat dikontrol, salah satunya dari asupan makan. Asupan karbohidrat merupakan faktor yang berpengaruh dengan kadar glukosa darah, namun asupan lemak, protein, dan serat juga mempunyai hubungan dengan kadar glukosa darah. Dalam penelitian ini, tidak terdapat perbedaan asupan karbohidrat, lemak, dan serat yang signifikan antara kelompok yang diberikan latihan yoga dengan kelompok yang tidak diberikan latihan yoga. Sedangkan untuk asupan protein menunjukkan ada beda antara kedua kelompok. Semakin tinggi asupan karbohidrat, protein, dan lemak maka kadar glukosa darah puasa juga semakin tinggi. Sedangkan serat berperan dalam pengontrolan kadar glukosa darah. Semakin tinggi energi berlebihan memacu resistensi insulin melalui peningkatan kadar glukosa darah dan asam lemak bebas di dalam darah. Konsumsi makanan tinggi kalori juga menyebabkan peningkatan lemak tubuh sehingga timbul obesitas yang erat hubungannya dengan resistensi insulin..$^{21,22}$

Tidak ada perbedaan asupan zat gizi energi, karbohidrat, lemak, dan serat selama intervensi pada kelompok perlakuan dan kelompok kontrol. Sedangkan itu, ada beda asupan protein pada kedua kelompok selama intervensi, dimana rerata asupan protein pada kelompok kontrol lebih besar dibandingkan kelompok perlakuan. Namun tidak ada pengaruh signifikan asupan zat gizi energi, karbohidrat, protein, lemak, dan serat terhadap kadar glukosa darah puasa subjek. Hal ini disebabkan karena subjek penelitian tidak dilakukan pengontrolan asupan makan selama intervensi.

\section{SIMPULAN}

Intervensi latihan yoga 10 kali pada wanita dengan kelebihan berat badan tidak berpengaruh signifikan terhadap penurunan kadar Glukosa Darah Puasa (GDP). Penelitian selanjutnya disarankan memperpanjang waktu intervensi latihan yoga dengan frekuensi yang teratur sesuai dengan jadwal yang telah ditetapkan. Peneliti juga sebaiknya memberikan intervensi modifikasi diet sehingga asupan makanan yang dikonsumsi subjek dapat dikontrol, serta mengontrol aktivitas fisik terutama olahraga sehingga aktivitas fisik subjek tidak menjadi bias dalam penelitian.

\section{DAFTAR PUSTAKA}

1. Soebagijo A, Novida Hermia, Achmad Rudijanto, et al. Konsesnsus Pengelolaan dan Pencegahan Diabetes Melitus Tipe 2 di Indonesia 2015. Jakarta: PB PERKENI. 2015

2. Wild S., Roglic G., Green A., Sicree R., King H., Global Prevalence of Diabetes: Estimates for The year 2000 and Projections for 2030. Diabetes Care. 2004; 27(5):1047-53

3. Misnadierly. Obesitas Sebagai Faktor Risiko Berbagai Penyakit. Jakarta: Pustaka Obor Populer. 2007

4. Badan Penelitian dan Pengembangan Kesehatan. Riset Kesehatan Dasar. 2013; 223-26.

5. Marni J. Armstrong, Sheri R. Colberg, Ronald J. Sigal. Moving Beyond Cardio: The Value of Resistance Training, Balance Training, and Other Forms of Exercise in the Management of 
Diabetes. Diabetes Spectr. 2015 Jan; 28(1):1423

6. Colberg SR, Sigal RJ, Fernhall B, et al. Exercise and type 2 diabetes: the American College of Sports Medicine and the American Diabetes Association: joint position statement executive summary. Diabetes Care. 2010; 33:2692-2696

7. Satchidananda SS. The Yoga Sutras of Patanjali. Buckingham, VA: Integral Yoga Publications. 2012

8. Kumar V, Jagannathan A, Philip M, Thulasi A, Angadi P, Raghuram N. Role of yoga for patients with type II diabetes mellitus: a systematic review and meta-analysis. Complement Ther Med. 2016; 25:104-112

9. Rioux JG, Ritenbaugh C. Narrative review of yoga intervention clinical trials including weight-related outcomes. Altern Ther Health Med. 2013;19(3):32-46

10. Santwana Mondal, Brajanath Kundu, Sukanta Saha. Blood Sugar and Lipid Profile Adaptations to Yoga Therapy. J Yoga Phys Ther. 2014; 4:4

11. Lorenzo A Gordon, Errol Y Morrison, Donovan A McGrowder, Ronald Young, Yeiny Terry Pena Fraser, Eslaen Martorell Zamora, Ruby L Alexander-Lindo, Rachael R Irving. Effect of exercise therapy on lipid profile and oxidative stress indicators in patients with type 2 diabetes. BMC Complementary and Alternative Medicine. 2008; 8:21

12. Malhotra V, Singh S, Tandon OP, Sharma SB: The beneficial effect of yoga in diabetes. Nepal Med Coll J. 2005; 7(2):145-147

13. Sahay BK, Murthy KJR, Raju PS, Madhavi S: Long term follow up on effect of yoga in diabetes in Baba Shole. Ed Diabetes Research in Clinical Practice. Abstracts of XIII Congress of IDF Abstract p 65-004-293- 655

14. Mercuri N, Olivera EM, Souto A, Guidi ML: Yoga practice in people with diabetes. International Journal of Yoga Therapy. 2003; 13:69-73
15. Lauche R, Ph D, Sibbritt D, Ph D, Ostermann T, $\mathrm{Ph} \mathrm{D}$, et al. Associations between yoga / meditation use, body satisfaction, and weight management methods: Results of a national cross-sectional survey of 8009 Australian women. Nutrition. 2017; 34:58-64

16. Bernstein a. M, Bar J, Ehrman JP, Golubic M, Roizen MF. Yoga in the Management of Overweight and Obesity. Am J Lifestyle Med. 2013; 8(1):33-41

17. Gordon L, Morrison EY, McGrowder D, et al. E Effect of Yoga and Traditional Physical Exercise on Hormones and Percentage Insulin Binding Receptor in Patients with Type 2 Diabetes. American Journal of Biotechnology and Biochemistry. 2008; 4(1):35-42

18. Rast, Sh. Dide, Hojjati, Z., Shabani, R. 2014. The Effect of Yoga Training on Blood Glucose, Insulin, and Resting Heart Rate in Type II Diabetic Females. Res. J. Sport. Sci. 2014; 2 (1): $15-21$

19. Ross A, Brooks A, Touchton-Leonard K, Wallen G. A Different Weight Loss Experience: A Qualitative Study Exploring the Behavioral, Physical, and Psychosocial Changes Associated with Yoga That Promote Weight Loss. Evidence-based Complement Altern Med. 2016; 2016:2914745

20. Mciver S, Mcgartland M, Halloran PO. “ Overeating is Not About the Food": Women Describe Their Experience of a Yoga Treatment Program for Binge Eating. Qual Health Res. 2009; 19(9):1234-45

21. Perkumpulan Endokrinologi Indonesia. Konsensus pengelolaan dan pencegahan diabetes mellitus tipe 2 di Indonesia. Jakarta: PB. PERKENI; 2006. Hal 3-14,30-31

22. Livesey, G. Hiroyuki, T. Interventions to lower glycemic response to carbohydrate foods with a low-viscosity fiber: meta-analysis of randomized controlled trials. J Clin Nutr. 2009; 89(1):114-25 